disinterestedness of gentlemen so united, -might suspect that private motives would operate in sustaining their public spirit. 'They might recollect the maxim of Rochefoucault-" L'intéret parle toutes sortes de langucs, et joue toutes sortes de personnages même celui de desintéressé."

But such uncharitable feelings inust subside when the Gazette assures its few dozen of readers that they are not just; for who can doubt its sincerity and truth? Is it Sir Benjamin's fault that so much public spirit resiles in his family? - is he to be blamed because his connexions are so anxious for the prosperity of the hospital, that they leave their shops and pay their money to support it as governors by their presence and subscriptions?-is he to be accused of forming a cabal because his lecturers, his friends, aye, and his friends' friends, happen to be all impelled at the same time to become governors of the institution, and to exercise their privileges for his advantage? Is it not, on the contrary, an aduirable thing that private fuelings and public interest run so well in harness ?-is it not a fortunate-a very fortunate circumstance-that a phalanx so compact should combine for purposes so pure?

Hudibras's squire hit the case exactly-

\footnotetext{
af 'Tis the temptation of the devil

That makes all human actions evil ;

1or saints may do the same things by

The spinit in sincesity.

Which other men ale tempted to,

And at the devil's instance do;

And yet the actions be contrary,

Just as the saints and wicked vary."
}

I said, sir, when I commenced this letter, that $I$ should not indulge in personality; and $I$ hope that in offensire personalities I have not indulged. I hare nttered no abuse, have called no names; and I th regret that it was necessary to mention individuals at all. They have been mentioned, it is true, but mentioned in a manner not inconsistent with gentlemanly feeling and propriety, and which the circumstances rendered imperative. Facts have been fairly laid before your readers, and no inferences have been drawn that might not justly follow from them, and from a knowledge of the workings of human nature.

I am, Sir, yours, \&c.,

A Govennor of ST. GEORgE's

June 5, 1835.

Hospitai.

** The language in several instances in the above letter appears objectionable, but with the exception of having curbed the expressions of indignation in one or two instances, we insert it verbatim. Comment is unnecessary.

\section{MR. HOARE AND MR. VICARY.}

\author{
To the Editos of The Lanciet.
}

Srn,-In the matter of Hoare, Vicary, and Curtis, we have discordant testimony, with as much discrepancy as we well can desire. Up to this date, so far as facts go, I consider Mr. Hoare the injured party; and, therefore, as he appeals to his professional brethren, and as it is a shocking thing for Mr. Curtis to labour under a conviction (which I think is a false impression) that his child would have been now living if a different plan of treatment had been pursued, I think that those members of the profession who intend to answer Mr. Hoare's call, should give their opinions. To what extent yon may be able to find space for such observations in The Lancret is another question.

To begin with Mr. Curtis, and then to speak of his child, of Mr. Vicary, and of Mr. Hoare.

Mr. Curtis.--Although mercurial fetor is peculiar, and mercurial inflammation of the gums is also peculiar, $I$ could not always give a decisive opinion, much less state positively, whether a person was or was not actually salivated from mercary. Then why should Mr. Curtis, or any other person, speak in such strong terms, when Mr. Hoare differs in opinion from him?

The Child.-1st. When the eruption of measles disappear's suddenly, is it uncommon to have a great determination of blood to some internal organ or surface? 2ndly. Was not the child probably in danger when Mr. Hoare first saw it? 3rdly. If we judge from the assertions (of both parties) already before us, was not the medicine prescribed very proper? 4thly. Have not most medical men seen spontaneous salivation under such circumstances? It is an odd term, but I mean appearances of salivation where no mercury, arsenic, nitric acid bath, or other medical means, have been in use. 5thly. Might not all these appearances and consequences be the result of destructive inflammation from congested vessels with weak action?

$M r$. Vicary. - Why did he not give a direct and satisfactory answer to $\mathrm{Mr}$. Hoare's questions in the notes? And why does he not appear in the matter?

Mr. Hoare.-To his first question the proper answer is, "Just possible but not probable." To his second "Certainly not to that alone." To his third, "Decisively not."

To sum up:-On the one hand I think it is straining probability to the utmost to suppose that in the case of (as Mr. Cur- 
tis says) a fine healthy child, having had a very mild attack of measles, attended by a slight cough (without inflammation or difticulty of breathing), the taking of six grains of calomel within sixteen hours would produce such a state of salivation as would alone destroy life; whilst, on the other hand, I think it is more than probable that such a child haring measles, even in a mild form, might suffer, on the jremature disappearance of the eruption, (here let me observe that the child became so ill as to lead the parent to call in professional aid) such a state of congestion in the vessels of the head and throat, as would alone occasion inflammation of an erysipelatous or destructive kind, producing the "sloughing of the tonsils," " swelled head," and all the other distressing appearances, and the fatal consequence related by Mr. Curtis.

From the evidence before us, then, it is my opinion, with due deference to all others in the profession,-

" 1st. That Mr. Hoare prescribed rery properly.

2 ndly. 'That, as he says, Sir A. Cooper might have had (and probably has had) an accident with mercury, though it is not proved, in this instance, that Mr. Hoare had one.

3rdly. That in this case no blame whatever attaches to $\mathrm{Mr}$. Hoare.

4thly. That it is not any great degree of charity or liberality towards Mr. Hoare, nor of the contrary towards $\mathrm{Mr}$. Vicary or Mr. Curtis, to say, that the imputations of the latter are not justifiable. I am, Sir, your obedient servant,

$$
\begin{gathered}
\text { Retford, Nottinghamshire, } \\
\text { June 15, } 1835 \text {. }
\end{gathered}
$$

[The foregoing communication was in type before the following letter reached us, and we certainly should not have printed another word on the subject, had the writer been any other person than Mr. Hoare himself, whose remarks, however, afford us so agreeable and vindicative a piece of penmanship, that we cannot refuse to give them insertion.-En. L.]

\section{To the Editor of Trie LANCET.}

SrR,-Mr. Vicary's well-known repugnance to Thri Lavcer, accounts probably for his having cats-pawed Mr. Curtis into the disrelishable task of vindicating him from the saspicion of having connived at certain gross imputations affecting my professional character. A horror of its integrity seems to have paralyzed his right hand, and Mr. Curtis, doubtless, writes while Mr. Vicary dictates. His prudence and good taste are in this respect remarkable. I imagine that a con* sciousness of guilt deters him from selfadvocacy; nor can he bring his mind to swallow the gall and wormwood of a forced appeal to the Editor of THE LANCET ; so nauseating a dose would almost be the death of him. On these grounds I would charitably explain his silence, although perbaps the truth may be that, like the dastardly Spanish soldier, he has committed suicide to avoid being slain in battle. If, however, he keeps aloof from fear, I would say to the little would-begreat medical Goliah of Warminster,

" Let him at once throw off the lion's hide,

And hang a cali-skin on his tecreant limbs."

Mr. Curtis's defence of Mr. Vicary is made up almost wholly of assumption and unsupported affirmation, and he meets my remonstrance by jumping at once to the notable conclusion of Mawworm, that "it's all a lie." Mr. Curtis is a schoolmaster, and, with the dogmatic air of a pedagogue, he asserts that his child's case was a very " mild" one, and that it hat no inflammation when 1 was called to it. If the case was so mild, why did he send to me urgently requesting my immediate attendance? And as to the inflammation, can Mr. Curtis, a non-jrofessional person, be supposed capable of deciding on the existence of a morbid state, often so insidious in its character as to embarrass the judgment of the most discriminating jractitioner? Mr. C. goes on to enumerate the proyressive symptoms of the case, summing them up, and calculating the product, with most complacent assurance. This seems to him a very easy affair-a sum in simple notation. The object of this recital is evidently to produce stage-effect - to convince your readers the child died from ptyalism, and that I was its murderer! But at every half-word he utters we hear the whisperings of the prompter, and the rehearsal is a most sorry one. Could any but a medical man, for instance, have given so accurate a detail of the symptoms of ptyalism, and could that medical man be any other than Mr. Vicary? But I can prove by undeniable evidence that no such symptoms (the sore mouth excepted) ever affected the child, and that the sore mouth, contrary to Mr. Curtis's affirmation, occurred on the evening when it took the first powder. I deny solemnly ever having used the word " accident" in alluding to $\mathrm{Sir} \mathrm{A}$. Cooper. All I said was - Had Sir A. Cooper attended the child the same results might have followed." Mr. C. next says that $I$ admitted the soreness of the child's mouth proceeded entirely from the powders. This assertion chimes well with the exaggerated tone of his whole series of averments. On my word of honour I merely admitted the 
possibility of the thing. In the absence of all other appearances of ptyalism I could have admitted nothing more.

It has been said that a man cannot have a greater enemy than an injudicious friend, and the discreditable light as regards medical etiquette in which $\mathrm{Mr}$. Vicary is made to appear by Mr. Curtis's next indiscreet statement, illustrates the truth of that apophthegm. Hear, reader, what he says:- "Mr. Vicary on his arrival said, 'I do not like to interfere with the patients of other medical men, and I cannot prescribe for your child excepr $\mathrm{Mr}$. Hoare is present. If you will see $\mathrm{Mr}$. H., and appoint a time, I will meet him here." "He adds, that he sent to apprise me of what had taken place, and that as he had lost all confidence in me he sent for Mr. Vicary again, who then saw the child. Hence it appears that in the morning sunshine Mr. V. could see his way-his steps were precise and straightforward; after sunset the evening shadows obscured his path-he lost himself, and his course was oblique and serpentine. He enunciates a rule and immediately violates it; an act which, as a schoolmaster, $\mathrm{Mr}$. Curtis must know would ensure the birch to any puling homunculus just ptat into his first breeches. Mr. C.'s honourable conduct is here on a par with Mr. Vicary's; he never expressed himself dissatisfied with my treatment of his chill, never apprised ne of his intention to call in another medical man, never acquainted me of Mr. V.'s proposal to meet me!

Mr. Curtis, still "doting on his own obsequious bondage," says he can corroborate his statements by the evidence of five respectable persons. Let him do so, I am prepared to meet them; but $I$ advise him to take care that in procuring the "endorsements" to the bill which he has drawn so fluently on his own invention, he does not enact the part of Fag to Captain Absolute, and injure his credit by offering too much security.

In conclusion, Mr. Curtis reproves me for not having kept my own council. Well done, Mr. Curtis, "Open rebuke is better than secret love:" so saith the Proverbs. My candour, it appears, then, is my greatest crime. I reply that I had no motive for concealment, I had done nothing wrong. Confident of the propriety of my treatment, I sought not to mystify. I leave concealment to men conscious of obliquity of intention and dishonesty of purpose, to the liers-in-wait for other men's reputations, who discharge their arrows of calumny from the dark ambush of covert malignity.

After all, the question whether the child was or was not salivated, is not the ques- tion to which $\mathrm{I}$ ought to nail Mr. Vicary. He knows, or ought to know, that my treatment was sanctioned by the first authorities; and whether he did or did not countenance the report that I had salivated the child and killed it; and his answer to my note is a tacit acknowledgment that he did. I contend that as a gentleman, as a man of honour, and as a Christian, when he knew that " rumour with her thousand tongues" was busy in assailing my professional reputation, he was bound to use his best endeavours to defend me, and not to have assisted in gorging with the foor? of slander the large swallow of public credulity. In his intercourse with his professional brethren, $\mathrm{Mr}$. Vicary's liberality has never been too conspicuous; but his prurient appetency for criticism will, it is to be hoped. in time coming, be indulged with more discretion, as long at least as he finds them conducting their practice on correct principles and with upright intentions.

I am, Sir, yours, \&c. JOHN HOARE.

Warminster, June 19, 1835.

CONDITION OF ASSISTANT - SURGEONS IN THE NAYY.

Expostulations of every kind fail at the Board of Admiralty to arouse the Lords Commissioners to a sense of the oppressed and degraded condition of the assistant-surgeons of the British navy. "Probably," says a despondent corre. spondent, " the simple statement of a case which has fallen under my own observation, may do something, even at the eleventh hour, to remedy the grievances which attend the prelimiriary steps in the naval medical service":-

Mr. A., a gentleman in manners, habits, and bearing, entered the navy medical service with a stock of professional knowledge, an excellent acquaintance with ancient and modern language, and possessed of all the other acquiremonts of a liberal education. His expectations in the service were high, and he at least expectcd the treatment of a gentleman and an off:cer while employed in it. He was appointed to an eighteen-gun brig, then fitting out in a dockyard. On examining the Navy List, the names of a commander, two lieutenants, a master, purser, and 